\title{
Sobre o problema da liberdade moral em Hume e Schopenhauer
}

\author{
On the problem of moral freedom in Hume and Schopenhauer \\ Rogério Moreira Orrutea Filho \\ Mestrando em Filosofia pela Universidade Estadual de Londrina (UEL) \\ E-mail: souaristocrata@hotmail.com
}

\begin{abstract}
Resumo: Neste trabalho pretende-se criar uma relação entre as doutrinas de Hume e Schopenhauer naquilo que se refere à questão da liberdade moral, com o objetivo de ressaltar suas similaridades, bem como suas diferenças. Mostra-se que tanto na filosofia de Hume, quanto naquela de Schopenhauer, a liberdade impõe-se como um problema geral que abrange problemas mais específicos, sobretudo o da definição das noções de vontade e caráter, e que, num primeiro momento, ambos assumem uma postura que pode ser considerada igualmente determinista. Porém, num segundo momento, os dois filósofos pretendem superar o determinismo, e é neste ponto em que se iniciam as diferenças entre seus respectivos pontos de vista. Suas propostas de superação do determinismo são igualmente exploradas ao longo deste artigo, e, ao final, concluímos que apenas Schopenhauer conseguiu apresentar uma solução coerente ao associar vontade individual humana com as noções de caráter inteligível, empírico e adquirido.
\end{abstract}

Palavras-chave: Liberdade; Vontade; Caráter.

\begin{abstract}
In this work, we want to create a relation between Hume's and Schopenhauer's doctrines about the question of moral freedom. Our objective is to highlight their similarities, as well their differences. We show that in both cases, freedom appears as a general problem which includes more specific problems, especially the definition of the notions of will and character, and, formerly, both philosophers assume a position that can be equally considered as determinist. However, afterwards they pretend to overcome the determinism, and at this point their differences begin to appear. Their suggestions of overcoming of the determinism are equally shown through this article, and, at the end, we conclude that only Schopenhauer could shown a coherent solution as he associates individual human will with the notions of intelligible, empirical and acquired character.
\end{abstract}

Keywords: Freedom; Will; Character.

\section{Introdução}

Certamente, todo debate que tenha a moral como objeto de apreciação filosófica, não pode escusar-se de qualquer tratativa acerca do problema da liberdade. Pois toda a filosofia moral constitui-se não somente em uma investigação sobre a definição dos princípios que devem determinar a conduta humana - a qual, em uma situação de adequação, merece a denominação de "conduta ética" 
- mas também se investiga as razões pelas quais estamos legitimados a julgar moralmente um indivíduo, vale dizer, atribuir mérito ou reprovação à sua conduta. E é neste contexto que a liberdade impõe-se como um pressuposto necessário; afinal, jamais se poderia atribuir mérito ou culpa ao agente moral caso este último já não fosse possuidor de liberdade de agir desta ou daquela maneira, isto é, se não the fosse possível escolher entre agir moralmente ou imoralmente. Neste sentido, a liberdade é um elemento intrínseco a todo fenômeno moral. Pode-se até cogitar a existência de outros fatores concorrentes; pois, sem dúvida, a questão do "por que agimos moralmente?” não se confunde com a questão do "por que estamos autorizados a emitir juízos de aprovação ou condenação?” ${ }^{1}$. Parece-nos que, com relação a este último ponto, a liberdade não poderia deixar de ser apontada como fundamento, de sorte que problematizar, ou colocar em dúvida a existência da liberdade, significa igualmente problematizar ou colocar em dúvida a legitimidade de toda e qualquer juízo de imputação. Em verdade, se a liberdade passasse a ser considerada mera fantasia ou efeito da ignorância humana, e se assumíssemos, portanto, o determinismo absoluto das ações do homem, então não poderia mais haver qualquer justiça na atribuição de mérito ou reprovação àquelas mesmas ações. A imputação, por sua vez, mesmo se considerada legitimada, leva-nos a um outro problema: a condenação, ou o mérito, devem recair sobre a ação do agente ou sobre o próprio caráter deste último? Afinal, em nossos raciocínios ou sentimentos morais constituídos cotidianamente, de que maneira compreendemos esta relação entre caráter do agente e sua conseqüente conduta?

Tais problemas receberam ampla atenção nas filosofias de Hume e Schopenhauer. Estes dois grandes filósofos trataram exaustivamente o problema da liberdade e o seu correlato, o determinismo, bem como todas as outras questões concorrentes, como aquelas da vontade, caráter, ação, e imputação. Veremos que, conquanto Hume e Schopenhauer se aproximem em muitos pontos significativos, suas conclusões principais permanecem radicalmente diferentes. Para mostrar isso, faremos uma análise paralela da maneira como é compreendida cada uma das noções que compõem a problemática da liberdade na obra de cada um dos dois filósofos. Destacaremos os problemas levantados e suas respectivas tentativas de solução. Começaremos analisando a causalidade, para esmiuçar a forma como é introduzida e compreendida tanto por Hume quanto por Schopenhauer. Ter em mente o alcance da noção de causalidade é de suma importância, uma vez que, na filosofia de Hume, a liberdade se apresenta no seio da determinação causal, e, para Schopenhauer, como um conceito negativo, vale dizer, liberdade entendida como ausência de causalidade. Em seguida, nossa análise se estenderá ao caráter e motivações humanas. E, por fim, veremos que, no que concerne à liberdade moral do ser

\footnotetext{
${ }^{1}$ Não estamos afirmando com isso que se deve oferecer um fundamento diferente para cada uma destas questões, mas apenas salientando a diferença significativa que há entre as mesmas.
} 
humano, a filosofia de Hume se envolve em contradições que podem ser resolvidas por propostas retiradas da filosofia de Schopenhauer.

\section{A causalidade}

Não seria possível compreender no que consiste a liberdade humana sem antes delimitar o significado e alcance da lei da causalidade. Há uma tensão natural entre estes dois conceitos: enquanto que a causalidade conduz ao determinismo, a liberdade, por outro lado, parece apenas poder se introduzir na ausência de qualquer determinação causal. Portanto, no que se refere à suposta liberdade das ações humanas, faz-se necessário empreender uma breve compreensão propedêutica sobre o modo como a causalidade é entendida por Hume e Schopenhauer, para então entendermos, com alguma segurança, até que ponto ela pode ou não ser aplicada sobre a conduta do homem.

\subsection{A causalidade segundo Hume}

As investigações céticas de Hume relativamente à causalidade possuem, basicamente, dois grandes objetivos: 1) desmistificar a concepção então vigente, segundo a qual a causalidade se constituiria em uma força misteriosa ou princípio oculto que gerasse uma conexão necessária entre objetos; 2) na desclassificação da causalidade enquanto ideia concebida a priori, para considerá-la mera conjunção entre dois objetos, dada a posteriori. Para alcançar estes objetivos, Hume sustenta inicialmente que todas as nossas percepções dividem-se em duas espécies: ideias e impressões. Estas duas classes de percepções seriam distintas entre si pelo seu grau de força ou intensidade. As percepções menos fortes seriam as ideias, e as mais fortes, as impressões:

Pelo termo impressão, entendo, pois, todas as nossas percepções mais vivas, quando ouvimos, vemos, sentimos, amamos, odiamos, desejamos ou queremos. E as impressões diferenciam-se das ideias, que são as percepções menos vivas, das quais temos consciência, quando refletimos sobre quaisquer das sensações ou dos movimentos acima mencionados (IEH, Seção 2, p. 36) ${ }^{2}$.

\footnotetext{
${ }^{2}$ HUME, D. IEH, seção 2, p. 36. Adoto as seguintes abreviaturas, para as obras de Hume: IEH (para Investigação acerca do entendimento humano) e TNH (para Tratado da natureza humana). Para as obras de Schopenhauer, adoto MVR I (para O mundo como vontade e como representação), WWV II (para Die Welt als Wille und Vorstellung - suplementos), F (para Über die Freiheit des Willens), M (paraSobre o fundamento da moral), P (para Parerga und Paralipomena), SG (para Über die vierfache Wurzel des Satzes vom zureichenden Grund). Os exemplares das obras em alemão são aqueles reunidos na Gesammelte Werke in zehn Bänden, da Diogenes, que por sua vez segue a edição histórico-crítica de Arthur Hübscher. As traduções dos trechos citados a partir das edições em alemão são de nossa inteira responsabilidade.
} 
Em razão desta "hierarquia" entre nossas duas classes de percepções - sendo a impressão a percepção mais forte, e o pensamento ou ideia a percepção mais fraca - Hume entende que todas as percepções mais fracas seriam cópias de nossas percepções mais fortes (impressões) ${ }^{3}$. Além disso, Hume compreende que a todo objeto do conhecimento aplicam-se três princípios de conexão: semelhança, contigüidade e causalidade ${ }^{4}$. Por outro lado, todos os objetos do conhecimento dividem-se em dois gêneros: relações de ideias e relações de fato ${ }^{5}$. A causalidade seria, de acordo com Hume, o princípio de conexão aplicável a todos os nossos raciocínios relativos a fatos ${ }^{6}$. Esta relação causal, aplicada a fatos, não poderia ser obtida mediante raciocínios a priori, mas seria sempre dada $a$ posteriori pela experiência, e se caracterizaria pela conjunção constante entre dois objetos ${ }^{7}$. Porém, o fundamento de semelhante conjunção não poderia ser encontrado em uma força ou princípio oculto que conectasse diferentes objetos e estados, mas no mero costume ou hábito ${ }^{8}$. Portanto, a causa seria "um objeto seguido de outro, de tal forma que todos os objetos semelhantes ao primeiro são seguidos de objetos semelhantes ao segundo", ou "um objeto seguido de outro cuja aparição faz convergir o pensamento sempre para aquele outro", isto é, mediante inferência; e todas as nossas noções de qualquer necessidade ou conexão seriam retiradas da observação de conjunções constantes de objetos semelhantes, a partir de impressões empíricas. O que importa frisar, é que Hume desejava, mediante estas considerações, apenas corrigir a noção de causalidade, mas não revogar a causalidade mesma. Assim, apesar de tudo, Hume sustenta uma visão profundamente determinista, o que ficará ainda mais evidenciado ao considerarmos sua teoria compatibilista da liberdade e necessidade.

\subsection{A causalidade segundo Schopenhauer}

Se Hume afirmava que a causalidade estava fundamentada no costume, isto é, na repetição habitual de um ato conferida empiricamente, sem que para tanto precisássemos recorrer a raciocínios ou processos do entendimento, em Schopenhauer, por outro lado, a própria experiência não poderia ser constituída simplesmente por sensações costumeiras ou instintos naturais ${ }^{40}$, mas deveria ter como

\footnotetext{
${ }^{3}$ HUME, D. IEH, Seção 2, p. 37.

${ }^{4}$ HUME, D. IEH, Seção 3, p. 40.

${ }^{5}$ HUME, D. IEH, Seção 4, p. 47. Quando Hume se refere aqui às "relações de ideias", "ideia" adquire um sentido muito estrito, porque se limita aos nossos raciocínios decorrentes da aritmética, álgebra e geometria. Diferentemente, quando ele se refere a "ideia" como espécie de percepção, "ideia" adquire um sentido mais amplo, porque referente a todo raciocínio abstrato e exercício de nossa imaginação a partir das sensações e impressões retiradas da experiência.

${ }^{6}$ HUME, D. IEH, Seção 4, p. 49.

${ }^{7}$ HUME, D. IEH, Seção 4, p. 50.

${ }^{8}$ HUME, D. IEH, Seção 5, p. 61.

${ }^{9}$ HUME, D. IEH, Seção 7, segunda parte, p. 86-87.

${ }^{40}$ Hume usa a expressão "instinto natural” para qualificar estas operações, simultâneas com a experiência, e que precedem o entendimento (cf. HUME, D. IEH, Seção 5, p. 64).
} 
pressuposto uma categoria do entendimento, válida a priori, sem a qual a experiência não apresentaria qualquer coerência ou sentido. Esta categoria do entendimento seria precisamente a causalidade. Schopenhauer provavelmente responderia a Hume que, o simples fato de realizarmos uma conjugação entre dois diferentes objetos ${ }^{11}$, já demonstraria que nossas impressões empíricas não são meramente passivas, mas estão acompanhadas por uma capacidade de intelecção sem a qual aquele fenômeno restaria totalmente incompreensível e vazio de sentido. Uma coisa seria simplesmente observar, na experiência, dois objetos ou estados completamente heterogêneos; outra, muito diferente, é incorporar nesta observação o entendimento segundo o qual há uma sucessão de eventos onde um evento causa o outro. Se tivéssemos apenas meras impressões no âmbito empírico, apenas a primeira opção seria válida, e nossas impressões não fariam sentido; mas como esta impressão é ao mesmo tempo intelectual, a segunda opção é aquela que realmente corresponde à experiência. $\mathrm{O}$ seguinte trecho, que agora passamos a transcrever, revela em linhas gerais o pensamento de Schopenhauer a este respeito:

Pois que coisa miserável é a mera sensação dos sentidos! Mesmo no mais nobre órgão do sentido, ela é nada mais que uma sensação local, específica, capaz de algumas variações dentro de seus limites, contudo em si mesma é sempre sentimento subjetivo, que enquanto tal nada traz de objetivo, portanto nada pode conter de uma semelhante intuição. Pois todo tipo de sensação é e permanece um processo no próprio organismo, mas enquanto tal limita-se à região abaixo da pele, e por isso jamais pode conter, em si mesma, algo oposto a esta pele, portanto jamais situaria algo exterior a nós. Ela pode ser agradável ou desagradável - o que expressa uma relação com nossa vontade - mas em nenhuma sensação jaz algo objetivo. Somente quando o entendimento [...] chega à atividade e emprega sua única e exclusiva forma, a lei da causalidade, ele efetua uma poderosa transformação, na medida em que a partir da sensação subjetiva passa a ser intuição objetiva. Ele compreende, em virtude de sua forma própria - portanto $a$ priori, i. e., antes de toda a experiência (pois esta não é possível antes disso) -, uma dada sensação do corpo como um efeito (que é uma palavra que somente ele, o entendimento, torna compreensível), o qual, enquanto tal, deve necessariamente ter uma causa. Ao mesmo tempo, o entendimento leva ao seu auxílio a forma predisposta do sentido exterior (o espaço) que jaz no intelecto, i. e., no cérebro, para transferir aquela causa para fora do organismo: pois somente por isso se forma para ele o exterior, cuja possibilidade já é o espaço; tanto que a intuição a priori deve conceder o princípio da percepção empírica. Por este processo, o entendimento [...] leva tudo ao seu auxílio, mesmo os dados mais minuciosos de uma determinada sensação, que a ela corresponde, para construir as causas destas mesmas sensações no espaço. No entanto, esta operação do entendimento [...] não é de modo algum discursiva, reflexiva, in abstracto, que se procede mediante conceitos e palavras; mas intuitiva e totalmente imediata. Pois somente por meio dela, consequentemente no entendimento e para o entendimento, apresenta-se o mundo corpóreo real, objetivo [...]. Logo, o próprio entendimento tem de produzir o mundo objetivo: mas o mundo não pode entrar dentro da cabeça já pronto de antemão, meramente através dos sentidos e dos orifícios de seus órgãos. Os sentidos não trazem nada além da matéria bruta, a qual o entendimento remodela, mediante as formas simples já citadas - espaço, tempo e

\footnotetext{
${ }^{11}$ A rigor, Schopenhauer não diria qualquer coisa sobre "conjugação entre dois objetos", pois a causalidade, de acordo com Schopenhauer, não se aplica na relação entre objetos, mas na relação entre diferentes estados (cf. SCHOPENHAUER, A. SG, § 20, p. 50 e ss.). Em razão do escopo deste trabalho, não vemos necessidade em aprofundar esta noção.
} 
causalidade - na percepção objetiva de um mundo corpóreo ordenado e regular. Logo, a nossa intuição comum, empírica, é uma do tipo intelectual [...] (tradução nossa) ${ }^{12}$.

Este trecho - que, a nosso ver, resume de maneira geral toda a compreensão de Schopenhauer sobre a causalidade - revela-nos que, apesar da causalidade ser uma categoria do entendimento válida a priori, no entanto ela não é uma operação abstrata, discursiva, mas contribui para a constituição do mundo objetivo tão logo este seja vivenciando, sem que seja necessário para tanto um esforço racional por parte do sujeito. Assim que percebe, o sujeito já entende. Consequentemente, Schopenhauer já supõe na percepção, ainda que meramente intuitiva - Hume a chamaria de impressão - uma atuação intelectual de nosso entendimento, através de sua "única e exclusiva forma, a lei da causalidade". A nosso ver, quando Schopenhauer descreve a ação do entendimento nestes termos, parece-nos já não haver mais uma diferença muito substancial entre esta e aquela outra operação do espírito, anterior a todo raciocínio abstrato, que Hume denominou simplesmente "instinto natural", na primeira parte da quinta seção da Investigação acerca do entendimento humano ${ }^{53}$.

Ao considerar a lei da causalidade como categoria do entendimento válida a priori, verdadeira conditio sine qua non de qualquer experiência, Schopenhauer adota o idealismo transcendental de Kant e a consequente distinção entre fenômeno (ou representação) e coisa em si. Daí Schopenhauer se referir normalmente à experiência empírica como a representações intuitivas, as quais "abrangem todo o mundo visível, ou a experiência inteira, ao lado de suas condições de possibilidade" ${ }^{14}$. Entre estas "condições de possibilidade" da experiência, contamos não somente a causalidade, mas também as formas puras de intuição, que são espaço e tempo. A experiência estaria então condicionada a duas formas de intuição, e a uma forma do entendimento. A pluralidade dos entes físicos, tão característica do mundo sensível, estaria condicionada pelo principio individuationis, que, por sua vez, decorreria da ação conjunta das duas formas de nossa intuição ${ }^{15}$. Portanto, as coisas apenas são individualizáveis porque situadas em diferentes pontos do espaço, e em diferentes momentos do tempo.

\section{A liberdade}

\footnotetext{
${ }^{12}$ SCHOPENHAUER, A. SG, $§ 21$, p. 67 e ss.

${ }^{53} \mathrm{O}$ que reforça a tese de que esta distinção seja apenas nominal, e não in re, é o fato de que a categoria da causalidade, apesar de ser condição da experiência, no entanto ela só se atualiza com a experiência. Schopenhauer chega a admitir que o entendimento precisa de "prática" (Uebung) e "experiência" (Erfahrung) para sua correta aplicação (cf. SCHOPENHAUER, A. SG, §21, p. 86). De qualquer forma, diante da proposta do presente trabalho, não faz sentido aprofundar mais suas similaridades e distinções neste aspecto particular.

${ }^{14}$ SCHOPENHAUER, A. MVR I, $\S 3$, p. 47/I 7.

${ }^{15}$ SCHOPENHAUER, A. MVR I, §23, p. 171/I 134.
} 
Bem entendido o alcance da causalidade, agora podemos avançar e explorar o tema central deste trabalho. Na síntese de sua compreensão, Schopenhauer e Hume exploram as noções de caráter e motivação, e aqui também aplicam a causalidade. O tópico seguinte será dedicado à exploração da articulação, realizada pelos dois filósofos, entre caráter e motivação, a partir da causalidade.

\subsection{Caráter humano e motivação}

A causalidade é o fio condutor através do qual Hume explora o problema da liberdade e da necessidade, pois ele compreende a relação existente entre motivos e atos voluntários - na esfera das ações humanas - de maneira análoga à relação de causa e efeito que presenciamos na natureza ${ }^{16}$, vale dizer: verifica-se uma conjunção entre motivação e uma determinada ação que se segue àquela motivação, tal como um efeito que deriva de sua causa, de sorte que toda ação humana está determinada e, portanto, é passível de ser compreendida e prevista a partir de inferências de nosso raciocínio e submetida a princípios, tal como os eventos naturais que nos cercam. Nestes termos, pode-se até mesmo alcançar uma evidência moral, da mesma forma que se alcança uma evidência natural. Afinal, a doutrina da necessidade aplica-se igualmente nos dois casos: as ações humanas e os fenômenos naturais compartilham os mesmos princípios ${ }^{17}$.

Contudo, deve-se sublinhar aqui que Hume compreende que a relação entre esta evidência moral e a evidência natural é de analogia, e não de identidade. Pois no que se refere às ações humanas, Hume articula outros elementos que não simplesmente aqueles contidos no mundo natural. Se na natureza apenas há uma conjunção entre objetos como figura e movimento - conjunção esta que, quando constante, torna-se habitual e autoriza-nos a chamá-la de conexão causal - no âmbito moral, por outro lado, a conjunção se dá entre uma outra classe de objetos: motivos e ações. Não somente isso: é possível ainda apontar a existência de uma natureza humana, imutável, na qual reside a estrutura de inclinações que funcionam como motivos para todos os seres humanos, isto é, como causas de suas ações:

Toda a gente reconhece que há grande uniformidade nas ações humanas em todas as nações e em todas as épocas, e que a natureza humana sempre permanece igual em seus princípios e em suas operações. Os mesmos motivos produzem sempre as mesmas ações; os mesmos eventos resultam das mesmas causas. A ambição, a avareza, o amor-próprio, a vaidade, a amizade, a generosidade e o espírito público, paixões misturadas em vários graus e distribuídas pela sociedade têm sido, desde o começo do

\footnotetext{
${ }^{16}$ HUME, D. IEH, Seção 8, p. 95.

${ }^{17}$ HUME, D. IEH, Seção 8, p. 96.
} 
mundo, e ainda são, a fonte de todas as ações e empreendimentos que se têm sempre observado entre os homens ${ }^{18}$.

Ao lado desta natureza humana, na qual reside aquilo que poderíamos considerar um caráter humano geral, há ainda os caracteres individuais, que compreendem o complexo de temperamentos, desejos e inclinações referentes a cada indivíduo considerado singularmente: "existem também caracteres peculiares a diferentes nações e a diferentes pessoas, e outros que são comuns a toda humanidade" 19 . Tem-se no caráter individual a marca distintiva da personalidade de cada ser humano. Supomos cotidianamente a existência de semelhante caráter ao atestarmos conhecer um determinado indivíduo, vale dizer, sempre que compreendemos alguma uniformidade e previsibilidade em sua conduta. Se cada indivíduo não tivesse seu caráter, e a experiência social não nos garantisse um certo conhecimento das disposições particulares de cada ser humano, então jamais poderíamos sequer ousar obter qualquer conhecimento sobre suas reações em determinadas circunstâncias, ou sobre a forma pela qual deveríamos dirigir nosso próprio comportamento diante daqueles indivíduos que julgamos conhecer. Portanto, dizer "eu conheço aquele indivíduo" significa afirmar também: "eu possuo algum conhecimento sobre as disposições que preenchem seu caráter, de sorte que posso obter alguma previsão de suas futuras ações". Consequentemente, em todos os nossos juízos ordinários, supomos a relação causal entre motivações que animam um caráter e ações que derivam a partir de tais disposições características. Segundo Hume, a relação causal estabelecida entre caráter, motivações e ações, é tão necessária quanto aquela aplicada aos objetos exteriores e inanimados conjugados na natureza, de sorte que, mesmo sobre a conduta dos homens, impera o determinismo. A indeterminação da conduta humana, que comparece em certos momentos, é apenas aparente; longe de negar o determinismo, apenas atesta nossa ignorância sobre as verdadeiras causas: o acaso não é prova da capacidade humana de indiferença, mas da imperfeição de nosso conhecimento ${ }^{20}$.

Se o comportamento humano é determinado na mesma medida que a ação de qualquer outro objeto, então a liberdade da vontade - isto é, o acaso ou a ausência de qualquer determinação causal sobre a vontade - só pode ser ilusória. Hume atribui duas razões à ilusão da liberdade. A primeira decorre da falsa concepção vulgar que se tem da causalidade, ao considerar esta como uma força oculta que coage os objetos, através de uma conexão necessária, a determinarem-se desta ou daquela forma ${ }^{21}$. Como não presenciamos a ação desta mesma força coativa sobre as operações de nosso espírito, julgamo-nos livres. Porém, ao corrigir a noção de causalidade, caracterizando-a como mera conjunção constante entre objetos, e como inferência que determina a existência de um a partir do outro, então é

\footnotetext{
${ }^{18}$ HUME, D. IEH, Seção 8, p. 91.

${ }^{19}$ HUME, D. TNH, Livro 2, Parte 3, Seção I, §10, p. 439.

${ }^{20}$ HUME, D. TNH, Livro 2, Parte 3, Seção 1, §12, p. 440.

${ }^{21}$ HUME, D. IEH, Seção 8, p. 98.
} 
fácil concluir que semelhante relação também se aplica aos atos humanos, pois é fácil verificar uma conjunção entre motivos e ações, o que implica uma evidência moral análoga à evidência física. A segunda é a falsa sensação ou experiência da liberdade de indiferença. Hume a explica nestes termos:

\begin{abstract}
A necessidade de uma ação, seja da matéria, seja da mente, não é, rigorosamente falando, uma qualidade do agente, mas sim de algum ser pensante e inteligente que possa considerar de fora a ação [...]. Sentimos que nossas ações, na maioria das vezes, estão submetidas a nossa vontade; e imaginamos sentir que a vontade ela mesma não está submetida a nada [...]. Podemos imaginar que sentimos uma liberdade dentro de nós, mas um espectador comumente será capaz de inferir nossas ações de nossos motivos e de nosso caráter. E, mesmo quando não pode fazê-lo, em geral conclui que o poderia, caso estivesse perfeitamente familiarizado com todas as circunstâncias de nossa situação e temperamento e com os mecanismos mais secretos de nossa constituição e disposição ${ }^{22}$.
\end{abstract}

Basicamente, a segunda razão contém um traço significativo da primeira, já que parte da falsa sensação de liberdade de indiferença decorrente do sentimento de submissão de nossas ações à nossa vontade, sem que uma força exterior provoque uma conexão necessária entre vontade e ato. Novamente, vale lembrar, que desmistificada a causalidade - isto é, considerada agora como conjunção habitual, e não como força física - aquela sensação subjetiva perde sua importância, pois já não pode mais servir como fonte de distinção entre as operações do espírito e as operações dos objetos exteriores. Nos dois casos, constata-se a conjunção entre dois objetos, sejam eles simples figuras e movimentos, sejam eles motivos e ações humanas. Como elemento novo, esta segunda razão chama a atenção para o fato de que a necessidade somente pode ser compreendida pelo observador, jamais pelo objeto observado. Provavelmente, Hume concordaria com Espinosa, quando este último diz que uma pedra, se tivesse consciência, acreditaria voar por vontade própria. Seu engano ficaria patente apenas para aquele que observasse o fenômeno. Aquilo que se enuncia subjetivamente como sensação clara de liberdade, é objetivamente evidenciado como fenômeno determinado pela rede de causas e efeitos.

Assim como Hume, Schopenhauer entende que qualquer fato da experiência é necessário: todas as representações intuitivas e empíricas que temos - sejam aquelas dos fenômenos da natureza, ou aquelas dos atos humanos - estão baseadas nas relações de causa e efeito. Em Schopenhauer, a necessidade é, de certa forma, ainda mais evidente e inexorável que em Hume, pois como mostrado anteriormente, a causalidade é considerada por ele uma lei do entendimento válida a priori; portanto, não está condicionada pela experiência (ou para se expressar como Schopenhauer, por nossas representações empíricas), mas se constitui ela mesma na própria condição de qualquer experiência. Uma experiência que não seja causal, não poderia ser uma experiência, ao menos não no sentido mais

${ }^{22}$ HUME, D. TNH, Livro 2, Parte 3, Seção 2, §2, p. 444-445. 


\section{ROGÉRIO MOREIRA ORRUTEA FILHO}

estrito do termo, que em Schopenhauer se limita às representações intuitivas. Os atos humanos, assim como todos os fenômenos da natureza, também nos são vivenciados a partir de representações intuitivas; consequentemente, estão igualmente submetidos à causalidade. A diferença é que, enquanto na natureza impera a causalidade em um sentido mais estrito, sobre a atuação humana a causalidade (em sentido amplo) toma a forma de lei da motivação ${ }^{23}$. Assim, tal como Hume, Schopenhauer é da opinião de que toda a conduta humana pode ser explicada pela equação entre o caráter do agente e as motivações que fazem efeito sobre o mesmo. Portanto, a ação não é livre, mas mero resultado daqueles dois elementos (caráter e motivos). "Sob a pressuposição da liberdade da vontade", escreve Schopenhauer, “cada ação humana seria um milagre inexplicável - um efeito sem causa. [...] diante disso, o entendimento (Verstand) permanece em silêncio: falta-lhe uma forma para pensar algo assim" 24 (tradução nossa). Em Sobre a liberdade da vontade humana, Schopenhauer realiza uma longa análise sobre cada uma das propriedades do caráter humano. De acordo com esta análise, o caráter seria:

I. Individual: o caráter "é distinto em cada um", ainda que "o caráter da espécie seja tido como fundamento (Grund) para todos, daí as qualidades comuns que se encontram em cada um"25 (tradução nossa). Consequentemente, tal como em Hume, em Schopenhauer também podemos distinguir um caráter específico - isto é, concernente às qualidades da espécie humana em geral - e um caráter individual, que marca o conjunto de motivos e inclinações particulares a cada homem considerado singularmente.

II. Empírico: o conteúdo do caráter (seja ele alheio ou próprio) não nos é dado a priori, mas apenas pela experiência pode ser conhecido ${ }^{26}$.

III. Constante: o caráter do homem sempre permanece o mesmo, ainda que passe por mudanças de idade, relações e conhecimento ${ }^{27}$.

IV. Inato: "é obra da própria natureza, e não de artifícios ou circunstâncias submetidas ao

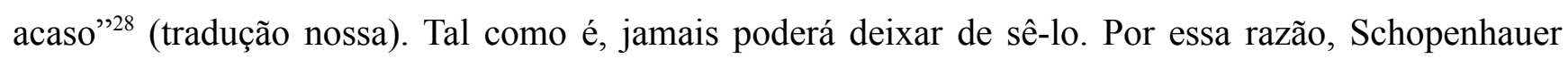
conclui que vício e virtude também são inatos ao homem ${ }^{29}$.

Por ora, é fundamental que entendamos as propriedades assinaladas nos itens I, III e IV. Todas elas apontam no sentido de que a conduta de cada indivíduo se encontra inteiramente determinada em razão da imutabilidade de seu caráter. Dado o caráter, e os motivos que correspondem a ele, segue-se

\footnotetext{
${ }^{23}$ SCHOPENHAUER, A. F, III, p. 70.

${ }^{24}$ SCHOPENHAUER, A. F, III, p. 84-85.

${ }^{25}$ SCHOPENHAUER, A. F, III, p. 87.

${ }^{26}$ SCHOPENHAUER, A. F, III, p. 87.

${ }^{27}$ SCHOPENHAUER, A. F, III, p. 89.

${ }^{28}$ SCHOPENHAUER, A. F, III, p. 92.

${ }^{29}$ SCHOPENHAUER, A. F, III, p. 92.
} 
de modo necessário a sua ação. Percebe-se que neste contexto - isto é, na avaliação do agir humano limitando a análise ao campo da experiência, vale dizer, no âmbito de nossas impressões ou representações intuitivas - Schopenhauer não se diferencia substancialmente de Hume, daí parecer-nos inteiramente correto aquele juízo segundo o qual Schopenhauer "reedita o argumento de Hume", pois assim como o argumento mais tarde apresentado por Schopenhauer, "o argumento de Hume consiste em dizer que do caráter se seguem as ações" ${ }^{30}$.

\subsection{Passagem do determinismo para a liberdade a partir da noção de vontade}

Embora Hume seja da opinião de que se opera a necessidade sobre a conduta humana - onde as noções de caráter, motivos e ações se articulam dentro de uma estrita relação causal - porém, sua real intenção não é negar a liberdade, mas reconciliá-la com o determinismo. Este "projeto de reconciliação" - na expressão do próprio Hume ${ }^{31}$ - é o que permite considerá-lo um filósofo compatibilista, na medida em procura mostrar que ação livre e determinismo são perfeitamente compatíveis $^{32}$. Passemos a examinar agora a maneira pela qual Hume conduz este empreendimento.

Segundo Hume, os dissensos filosóficos sobre a questão da liberdade e determinismo deitam suas raízes na falta de definição destes dois termos. A partir de todas as considerações precedentes sobre a causalidade, pode-se compreender melhor a definição que Hume confere à necessidade: "defino a necessidade de duas maneiras, de acordo com as duas definições de causa, da qual ela é um componente essencial. Situo a necessidade seja na união e conjunção constante de objetos semelhantes, seja na inferência da mente de um ao outro" ${ }^{33}$. Considerando esta definição de necessidade, a liberdade, se definida como mera ausência de necessidade, identificando-se com o acaso, teria de ser totalmente suprimida; mas Hume acredita que esta supressão faz-se desnecessária caso se adote uma definição correta de liberdade: "por liberdade, então, podemos apenas entender um poder de agir ou de não agir segundo as determinações da vontade" ${ }^{34}$. Assim, Hume "compatibiliza" o rigor determinista nas ações humanas com a liberdade das mesmas: toda conduta é efeito de uma motivação - a qual, por sua vez, manifesta-se dentro dos limites da natureza humana geral e caráter humano individual - e, consequentemente, é necessária; mas se é adotada a definição segundo a qual a liberdade é nada mais que o poder de agir ou de omitir-se (o que não deixa de ser também uma forma de agir) de acordo com a própria vontade, então seria plenamente possível, pensa Hume, afirmar que o ser humano é

\footnotetext{
${ }^{30}$ PAVÃO, Aguinaldo. O mal moral em Kant, p. 73.

${ }^{31}$ HUME, D. IEH, Seção 8, p. 100.

${ }^{32}$ COSTA, Claudio. Livre arbítrio: como ser um bom compatibilista, p. 20.

${ }^{33}$ HUME, D. TNH, Livro 2, Parte 3, Seção 2, §4, p. 445.

${ }^{34}$ HUME, D. IEH, Seção 8, p. 100.
} 
determinado e, ao mesmo tempo, livre. Pois de acordo com este conceito de liberdade, o ponto terminal é a vontade. Considerada dentro destes limites - da mera adequação entre ação e vontade - a liberdade pode novamente se reafirmar. Hume vai ainda mais além. Ele entende que mesmo a obediência às leis, sejam elas divinas ou humanas, não pode estar fundamentada em um livre-arbítrio de indiferença, mas no próprio determinismo ou necessidade:

De fato, como todas as leis humanas estão fundadas em recompensas e punições, admite-se certamente como um princípio fundamental que estes motivos exercem uma influência sobre a mente, produzindo boas ações e impedindo as más. Podemos dar a essa influência o nome que bem entendermos; mas como usualmente, ela ocorre em conjunção com a ação, o bom senso requer que a consideremos uma causa, e a vejamos como um exemplo dessa necessidade que pretendo estabelecer ${ }^{35}$.

Isso afeta de modo substancial a imputabilidade. Embora Hume não o diga explicitamente, parece-nos plenamente justo concluir que a imputabilidade, de acordo com este ponto de vista, também estaria fundada na necessidade: por causa da passividade humana diante de motivos e contra-motivos expressos na forma de leis, justifica-se a punição. Jamais seríamos punidos se fôssemos insensíveis ou incapazes de sermos determinados pelas penas e recompensas oferecidas pelo ordenamento jurídico vigente. Deve-se reconhecer que há alguma coerência neste raciocínio de Hume, sobretudo se consideramos o fato de que animais irracionais jamais poderiam ser punidos, justamente pela impossibilidade de se deixarem determinar pela letra de uma norma jurídica qualquer. Para os animais irracionais, o direito não oferece motivos; logo, não é possível estabelecer, nestas circunstâncias específicas, um enlace causal entre o comportamento dos animais e suas motivações. Além disso, se não fôssemos capazes de estabelecer uma relação causal entre ação e agente, jamais poderíamos atribuir mérito ou culpa ao agente. A conduta perece no tempo, e não se constitui em uma entidade; logo, a conduta, tomada em si mesma, não pode ser responsabilizada; apenas o agente pode. Sem o nexo causal entre a pessoa do agente, e a ação que resulta de suas disposições características, não poderia haver objeto de mérito ou reprovação. Apenas porque ligamos causalmente ação e agente (aquela sendo derivada deste), é que o sistema jurídico adquire um objeto de mérito ou reprovação na pessoa do próprio agente. Em suma: sem a constituição de um nexo causal entre o sujeito e sua respectiva conduta, não poderia haver um ponto terminal de imputação. Consequentemente, a imputabilidade estaria fundamentada na necessidade, e não na liberdade entendida como ausência absoluta de determinações causais:

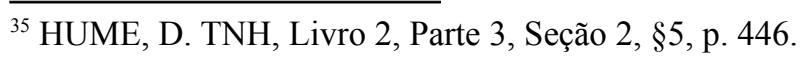


Segundo a doutrina da liberdade, portanto, um homem continua tão puro e imaculado após ter cometido o mais terrível dos crimes, como no momento de seu nascimento; suas ações não atingem em nada seu caráter, pois não derivam dele [...]. Somente segundo os princípios da necessidade alguém pode adquirir mérito ou demérito por suas ações $[\ldots]^{36}$.

Por outro lado, se mostramos no tópico anterior o quanto Hume e Schopenhauer concordavam entre si naquilo que se refere à necessidade, na questão da liberdade o que se verifica é um profundo dissenso. Vimos que Schopenhauer julgava ser impossível compreender qualquer experiência - que é uma espécie de representação intuitiva - sem o auxílio da causalidade, a qual seria uma lei do entendimento válida a priori, e, por essa mesma razão, elemento constituinte de toda experiência possível. No entanto, ao considerar a causalidade uma categoria a priori do entendimento, Schopenhauer retoma a noção kantiana segundo a qual os fenômenos - que são as representações que se tem a partir das formas apriorísticas do intelecto - não poderiam ser confundidos com as coisas em si mesmas, isto é, quando consideradas independentes de nosso aparato de cognição. Mas neste aspecto, resta uma grande distinção entre Kant e Schopenhauer: enquanto que o primeiro nada disse sobre a coisa em si, o segundo julgou encontrá-la na vontade. Mas esta profunda diferença não impediu que Schopenhauer retomasse uma outra noção kantiana: a de mundo inteligível, contraposta à de mundo sensível. De acordo com Kant, a contradição entre a liberdade suposta no âmbito moral e a necessidade suposta no âmbito físico - contradição esta que compõe o "terceiro conflito das idéias transcendentais da antinomia da razão pura" ${ }^{37}$ - poderia ser resolvida através da admissão de uma esfera inteligível - à qual o homem seria pertencente enquanto ser livre, considerado em si mesmo - e de uma esfera sensível - à qual o homem pertenceria enquanto ser determinado, fenômeno natural. Esta distinção não seria arbitrária, porque resultaria da diferenciação entre fenômeno e coisa em $\mathrm{si}^{38}$; além disso, a mesma "consciência de si" (Bewusstsein seiner selbst) que enuncia o determinismo que impera sobre todo ente natural, é aquela que também enuncia a própria liberdade do homem enquanto inteligência moral ${ }^{39}$. Portanto, derivam da mesma autoridade e, consequentemente, devem ser igualmente autênticos. Disso resulta que o homem seria portador de um caráter empírico, "mediante o qual suas ações, enquanto fenômenos, se interconectariam completamente com outros fenômenos segundo leis constantes da natureza", e de um caráter inteligível, o qual não se subordina a "quaisquer condições da sensibilidade e não sendo, pois, um fenômeno" ${ }^{40}$. Schopenhauer adiciona a isto algumas noções teóricas. Ao localizar o em si do homem na vontade, compreende que esta está além das leis

\footnotetext{
${ }^{36}$ HUME, D. TNH, Livro 2, Parte 3, Seção 2, §6, p. 447.

${ }^{37}$ KANT, I. Crítica da razão pura, p. 294.

${ }^{38}$ KANT, I. Grundlegung zur Metaphysik der Sitten, p. 86-87/BA 196-107.

${ }^{39}$ KANT, I. Grundlegung zur Metaphysik der Sitten, p. 94/BA 117.

${ }^{40}$ KANT, I.. Crítica da razão pura, p. 341-342.
} 
que determinam o mundo da natureza, vale dizer: a vontade, enquanto coisa em si, é livre, pois a causalidade apenas se aplica aos fenômenos, mas jamais à coisa em si. Consequentemente, o caráter empírico, que se desenvolve no espaço, no tempo, e sob a lei da causalidade, é mero fenômeno, apenas manifestação do caráter inteligível, o qual, por sua vez, é um "ato extratemporal, indivisível e imutável da Vontade" ${ }^{41}$, isto é: aquilo que o homem é empiricamente decorre daquilo que ele quer extratemporalmente. Assim, a essência, ou caráter inteligível, é de inteira responsabilidade do indivíduo. Porém, este querer deve ser entendido como um ato voluntário extratemporal, do contrário estaria subordinado às mudanças, ou, o que é o mesmo, à lei da causalidade. Nesta circunstância, a vontade não poderia ser livre. Mas como o caráter inteligível já é esta vontade individual, considerada em sua absoluta liberdade porque situada fora do espaço e do tempo, alheia a qualquer determinação causal, pode-se dizer que cada indivíduo - e, conseguintemente, cada caráter inteligível que se manifesta no mundo dos fenômenos como caráter empírico - é sua própria obra. Os atos individuais apenas revelam o que o agente já é; mas o que ele é, é aquilo que ele quer extratemporalmente. No mundo dos fenômenos, verifica-se que o operari ("agir") se segue ao esse ("ser") ${ }^{42}$. Por isso, como o mundo dos fenômenos apenas se refere ao operari - porque somente revela atos que se desenvolvem sob a égide da causalidade - a liberdade empírica da vontade não passa de ilusão. Mas a liberdade transcendental, referente ao esse, isto é, ao caráter inteligível - o qual é a própria vontade na sua atuação extratemporal - não pode ser negada ${ }^{43}$. Assim, a rigor, o que é negado pela filosofia de Schopenhauer é tão-somente a liberdade dos atos individuais, tal como estes se desenvolvem no mundo dos fenômenos. A liberdade da vontade, por sua vez, é inteiramente preservada. Apesar de em alguns trechos Schopenhauer se referir à liberdade da vontade como algo inteiramente necessário ${ }^{64}$, julgamos que o mais correto, para se manter coerente com a própria doutrina, seria fazer uma rígida distinção entre liberdade da vontade individual e liberdade dos atos individuais ${ }^{45}$. Em Schopenhauer, a necessidade recai tão-somente sobre o operari, isto é, sobre os atos que se desenvolvem no espaço e no tempo e sob a lei da causa e efeito; sobre o ser ou caráter inteligível, que já é a própria vontade em sua atuação extratemporal - e aqui a expressão "atuação" deve ser entendida em um sentido diverso daquele que se atribui ordinariamente aos atos que se desenvolvem no mundo dos fenômenos - não recai necessidade alguma: é inteiramente livre. Portanto, não podemos concordar com aqueles que

\footnotetext{
${ }^{41}$ SCHOPENHAUER, A. MVR I, §55, p. 375/I 341.

${ }^{42}$ SCHOPENHAUER, A. M, $§ 10$, p. 95.

${ }^{43}$ SCHOPENHAUER, A. MVR I, §55, p. 376/I 342.

${ }^{64}$ Perfeito exemplo disso é um trecho já citado neste trabalho (cf SCHOPENHAUER, A. F, III, p. 84), no qual Schopenhauer usa a expressão Willensfreiheit ("liberdade da vontade"), onde, de acordo com nosso ponto de vista, ele deveria ter usado algo como Freiheit der Taten ("liberdade dos atos").

${ }^{45}$ Christopher Janaway parece ter explorado esta diferenciação, ao menos no que se refere à necessidade reservada tão-somente aos atos individuais, ainda que de forma não suficientemente explícita e declarada (cf. JANAWAY, Christopher. Schopenhauer's philosophy of value, p. 7-8).
} 
consideram Schopenhauer um representante do determinismo. A isso podemos acrescentar que a consciência da responsabilidade não é considerada erro ou ilusão em sua filosofia, e sim prova da existência da liberdade: "somos pois conscientes da liberdade mediante a responsabilidade: onde esta se encontra aquela também tem de se encontrar" ${ }^{\prime 4}$.

Pode-se objetar nosso entendimento com o argumento segundo o qual a liberdade de vontade, em Schopenhauer, não pode ser individual, pois a individualidade é um artifício do principii individuationis; assim, valeria apenas enquanto representação. A vontade enquanto coisa em si, única portadora da liberdade, não se individualiza, de forma que jamais poderia se falar em uma liberdade atribuível aos indivíduos. E se não se atribui liberdade aos indivíduos, então a consciência da responsabilidade individual não passaria de erro ou ilusão. Estamos plenamente cientes destas dificuldades. Porém, a individualidade não pode se resolver apenas no principio individuationis, devendo estar fundamentada também na vontade enquanto coisa em si:

Individualidade, sem dúvida, é inerente sobretudo ao intelecto, que, refletindo o fenômeno, é a ele relativo, e o fenômeno tem o principium individuationis como sua forma. Mas individualidade é também inerente à vontade, na medida em que o caráter é individual [...] (tradução nossa) ${ }^{47}$.

Em Parerga und Paralipomena, mais precisamente no capítulo dedicado à ética, encontramos o seguinte trecho, que revela o mesmo sentido que o anterior, apenas com o significativo acréscimo do reconhecimento do mistério que gira em torno da individualidade:

Disso se segue que a individualidade não se baseia apenas no principio individuationis, e portanto não é simplesmente fenômeno; mas que ela se enraíza na coisa em si, na vontade do indivíduo: pois o seu próprio caráter é individual. Porém, quão profundas são estas raízes, é uma questão cuja resposta eu não posso dar (tradução nossa) ${ }^{48}$.

Portanto, não se pode afirmar que a individualidade esteja fundada apenas e tão somente no princípio de individuação, já que o próprio caráter, sem dúvida, é individual. E que da individualidade do caráter decorra a inerência da individualidade na vontade, tal fato se dá porque o caráter não é mero artifício do intelecto, mas já é a própria vontade. Portanto, "vontade individual” não pode ser, de modo algum, entendida como simples fenômeno ${ }^{49}$. Por essa mesma razão, Schopenhauer qualifica, por vezes,

\footnotetext{
${ }^{46}$ SCHOPENHAUER, A. M, $\S 10$, p. 97.

${ }^{47}$ SCHOPENHAUER, A.WWV II, 48, p. 713.

${ }^{48}$ SCHOPENHAUER, A. P II, §116, p. 248.

49 Justamente porque queremos sublinhar aqui este aspecto do pensamento de Schopenhauer, é que não adotamos a distinção entre "Vontade" - com inicial maiúscula, para designar vontade enquanto coisa em si una e indivisa em todo e qualquer fenômeno - e "vontade" - com inicial minúscula, para designar o simples fenômeno da Vontade. Parece-nos que semelhante distinção, adotada por comentadores como Dale Jacquette (por exemplo, in JACQUETTE, D. The philosophy of Schopenhauer, p. 77) e na excelente tradução de Jair Barboza, faz-nos assumir um puro dualismo entre Vontade
} 
o caráter inteligível como a "essência em si" da coisa singularmente considerada ${ }^{50}$. O que se quer dizer com isso, é que o fato de um indivíduo se distinguir de outro indivíduo na sua própria volição - isto é, no seu complexo de inclinações e desejos, em suma, em seu caráter - não se reduz em uma mera distinção entre relações de espaço e tempo (princípio de individuação), justamente porque a distinção de volição é uma distinção de caráter, e não de linhas e pontos espaciais ou momentos temporais. Ora, se a distinção, neste caso, não pode ser explicada à luz de qualquer forma a priori de intuição, então ela não pode estar subordinada à mera representação. Neste ponto, a individualidade se certifica nesta vivência totalmente a posteriori que temos de nós mesmos, isto é, no conhecimento que adquirimos de nosso caráter empírico, o qual, por sua vez, é desenvolvimento temporal de nosso caráter inteligível. E se a distinção entre os indivíduos se encontra no fato de que cada um possui seu caráter inteligível, então a individualidade já não pode ser apontada como simples fenômeno ou representação, uma vez que o caráter inteligível não é fenômeno ou representação, mas reside na esfera do em si. Obviamente, este ponto traz grandes dificuldades. Brian Magee, por exemplo, julga incoerente as explicações de Schopenhauer sobre a liberdade individual, justamente porque

Não temos razões para acreditar que há outra coisa além do noumenon, único e indiferenciado [...] independente do tempo e espaço. Então, o que é aquilo que pode ter escolhido ser eu? Não eu, certamente. Só poderia ser o noumenon, pois não há nada além disso, e aquele mundo fenomênico no qual ele se manifesta. (tradução nossa) ${ }^{51}$

Julgamos que o erro de Magee consiste em assumir uma distinção baseada única e exclusivamente na rígida bifurcação entre coisa em si, una e indivisa, e simples fenômenos, sem considerar esferas intermediárias entre estes dois extremos. Sabe-se, por exemplo, que as Ideias em sentido platônico ou "graus de objetivação da vontade" - introduzidos no segundo livro de $O$ mundo como vontade e representação, e exploradas detalhadamente no terceiro livro da mesma obra - não encontram uma posição satisfatória neste simples esquema dual. E, a isso, acrescentamos que a individualidade humana compartilha do mesmo problema que as Ideias: embora não seja coisa em si una e indivisa, tão pouco é simples fenômeno. Por isso, pensamos que a solução mais satisfatória seja admitir que o status ontológico da individualidade, em Schopenhauer, não é o de coisa em si una e indivisa, e nem de simples fenômeno submetido ao espaço, tempo e causalidade; nossa individualidade moral - para se distinguir da mera individuação fenomênica - está situada numa esfera

enquanto coisa em si e simples fenômenos, sem considerar possíveis esferas intermediárias. Mas de acordo com nossas explicações, a vontade individual, embora não possa ser identificada com a Vontade una e indivisa, tão-pouco pode ser qualificada como simples fenômeno. Simples fenômeno é o caráter empírico; o caráter inteligível, e, consequentemente, a individualidade, já estão situados em uma esfera transcendental, sem, no entanto, serem coisas em si.

${ }^{50}$ Por exemplo, em SCHOPENHAUER, A. M, §10, p. 96.

${ }^{51}$ MAGEE, B. The philosophy of Schopenhauer, p. 207. 
transcendental, sem, contudo, identificar-se com a coisa em si una e indivisa. Uma explicação que procurasse ir além disso seria impossível e ociosa, justamente porque já nos encontramos em uma esfera transcendental para a qual a linguagem mostra-se insuficiente na realização de sua função descritiva. Portanto, aqui convém empregar a linguagem apenas de maneira negativa, isto é, não enumerando exaustivamente os predicados da individualidade, mas apenas evidenciando aquilo que a individualidade não é: e ela, individualidade em seu sentido moral, isto é, enquanto caráter inteligível de cada indivíduo humano, não pode ser considerada mero fenômeno. Consequentemente, conclui-se que, em Schopenhauer, não somente a individualidade não pode ser considerada como simples representação, mas, pela mesma razão, tão pouco a liberdade e responsabilidade individuais são ilusórias.

Segue-se de tudo isso que Schopenhauer não pode ser taxado de compatibilista, ao menos não no mesmo sentido que Hume, por duas razões: 1) necessidade e liberdade não são conciliadas nos limites de uma visão unidimensional, como em Hume, mas apenas numa perspectiva bidimensional do homem (que deve ser visto como fenômeno, mas também como coisa em si); 2) Em Schopenhauer, a necessidade vale apenas para a representação, vale dizer, é produto de um artifício intuitivo-intelectual. $\mathrm{Na}$ sua realidade última, em seu "em si", o homem é inteiramente livre. A necessidade dos atos individuais é mera representação, tal como estes atos mesmos; em última instância, o que realmente se verifica é a liberdade da vontade ${ }^{52}$.

\subsection{Observações críticas à doutrina da liberdade de Hume}

As definições de Hume sobre liberdade, e o modo como articula neste contexto caráter, motivos, e ações, levam-nos a algumas conclusões bastante insatisfatórias. Em primeiro lugar, (I) a filosofia de Hume não consegue explicar de maneira coerente o fenômeno da imputação a partir de suas premissas deterministas. Pode-se facilmente conceber que a lei opera como sistema de oferecimento de motivos e contra-motivos ao agente; no entanto, se retomarmos as definições de Hume sobre "natureza humana" - que é estática ou imutável em suas linhas essenciais - e a maneira

\footnotetext{
${ }^{52}$ Cabe observar que Schopenhauer desenvolve também uma outra teoria da liberdade, a qual, contraposta à liberdade transcendental, seria a liberdade adquirida no mundo dos fenômenos, exposta por Schopenhauer no quarto livro de $O$ mundo como vontade e representação. Tal liberdade consistiria na "negação" ou "autossupressão" da vontade individual. Através disso, o próprio caráter individual é negado ou suprimido, e, consequentemente, também o jogo de motivos e inclinações correspondentes a ele. Justamente por isso, esta espécie de liberdade não foi objeto de apreciação deste trabalho, pois aqui nos interessa a liberdade que se dá através da afirmação ou exercício da vontade, e não através de sua supressão. Também é digno de nota que esta liberdade enquanto autossupressão da vontade é adquirida apenas por uma classe muito restrita de indivíduos, que são os ascetas e santos, e, por conseguinte, não serve de fundamento para a imputabilidade moral e criminal, que se aplica aos homens em geral e que será mais explorada a seguir. E, por fim, esta espécie de liberdade não pode ser relacionada à doutrina de Hume acerca da liberdade, justamente porque Hume tratou exclusivamente da liberdade em termos de afirmação volitiva, e como suposto fundamento da imputação moral e criminal.
} 
como o mesmo aplica os "princípios da necessidade" aos atos humanos - estabelecendo um determinismo rígido entre motivos e ações - veremos que toda sua filosofia aponta no seguinte sentido: de que o caráter do agente é imutável e, consequentemente, sua rede de motivações sempre se manifestará nos limites de suas disposições características, de sorte que um homem de caráter predominantemente torpe, cujas inclinações são, em sua grande maioria, cruéis e egoístas, jamais, ou ao menos muito dificilmente, poderá ser determinado por motivos nobres ${ }^{53}$. Se assim não fosse, Hume jamais poderia falar em uniformidade da conduta humana. A uniformidade pressupõe a imutabilidade não só da natureza humana, mas também do caráter individual. Se há uniformidade, é porque o indivíduo não possui a capacidade de mudar a qualquer momento aquilo que já é. E como o próprio Hume diz, quando não conseguimos inferir a conduta a partir do agente, isso se deve não à espontaneidade do mesmo, mas a nossa ignorância com relação às disposições compreendidas em seu caráter. Nestes termos, com que justiça poderíamos, por exemplo, culpar um homem cujas inclinações fossem predominantemente malévolas e, portanto, bastante insensível aos incentivos legais? Em tais circunstâncias certamente poderíamos atribuir-lhe seus atos, mas jamais culpá-lo por ser aquilo que é. Portanto, faz-se necessário pressupor uma liberdade tornar-se aquilo que é. Porém, em Hume, não poderia haver semelhante liberdade, pois a sua própria definição de liberdade situa-se unicamente na compatibilidade entre ação e vontade. E a vontade, por sua vez, já é uma disposição característica do agente: ele não poderia querer aquilo que contrariasse suas disposições de caráter. Portanto, por mais que Hume se esforce, uma compreensão puramente empírica e causal do fenômeno moral jamais poderia explicar, de forma coerente, a imputabilidade, muito menos justificá-la.

Em segundo lugar, (II) o compatibilismo humeano peca por contrariar frontalmente o princípio da não-contradição. Ao definir liberdade como "poder de agir ou não agir de acordo com a própria vontade", e ao mesmo tempo afirmar a mais absoluta necessidade das ações humanas, Hume forçosamente conclui que o homem é e não é livre. Como não pode haver nada de compreensível na realidade que viole o citado princípio, então somos forçados e procurar o erro de Hume: se localizado na tese a favor da necessidade das ações humanas ou na tese da liberdade. Tertio non datur. Partindo de todas as premissas e desenvolvimentos argumentativos de Hume, parece-nos evidente que sua filosofia aponta apenas para o determinismo de nossas ações. Pois suas teses a favor da necessidade compreendem a totalidade de elementos que compõem o fenômeno da conduta humana; por outro

\footnotetext{
${ }^{53}$ Deve-se lembrar que em Hume há, ao lado de um caráter humano geral ("natureza humana"), um caráter humano específico, isto é, individual. Assim, temos estas duas estruturas de motivações: uma geral, outra específica. E, embora Hume não o faça de explícito e sistemático, podemos dizer que o caráter humano geral compreende as mais diversas motivações, que acometem, de modo geral, todo indivíduo: inveja, amor, egoísmo, compaixão etc. Mas os caracteres individuais se distinguem entre si através da predominância de uma inclinação sobre a outra. Assim podemos conceber um indivíduo que é predominantemente egoísta, e outro que é predominantemente compassivo. Tais gradações são tão infinitas quanto a diversidade de temperamentos e personalidades podem sê-lo.
} 
lado, sua definição de liberdade é abstrata no pior sentido do termo, porque se trata de uma definição que desconsidera todas as outras partes que compõem a totalidade do fenômeno humano em pauta, para privilegiar apenas alguns poucos elementos - que são, a saber, apenas a passagem da vontade à ação - e, inexplicavelmente, esquecer ou ignorar o mais importante (isto é, se o indivíduo afinal pode ou não escolher aquilo que é). Sua definição de liberdade só se sustenta nos limites de semelhante abstração. E não poderia ser de outra forma: na visão unidimensional de Hume - na qual a causalidade opera de modo absoluto - a liberdade só poderia exprimir-se através da intencional ignorância em relação a todos os outros elementos que compõem a totalidade da vida moral. Se Hume adicionar qualquer outro elemento desta totalidade em sua definição abstrata, a liberdade restaria prejudicada e já não poderia mais ser definida, mas apenas negada. Assim, por exemplo, se ele complementasse sua definição de liberdade da seguinte maneira: "poder de agir ou de não agir de acordo com a própria vontade, sendo esta uma disposição do caráter imutável do agente", é fácil perceber que a liberdade desapareceria e cederia lugar, mais uma vez, à necessidade. O ponto terminal da definição seria transferido para o caráter, o qual, no entanto, transcende o mero ato de volição do agente. O agente poderia agir de acordo com sua vontade; mas ele não poderia determinar o próprio querer tal como determina seu próprio ato, uma vez que sua vontade decorre de suas tendências e inclinações que compõem o complexo do seu caráter imutável. No sistema de Hume, só há liberdade na medida em que suspendemos nosso saber sobre todas as outras informações que o próprio Hume nos ofereceu, vale dizer, devemos nos tornar temporariamente cegos em relação ao problema realmente capital, isto é, se somos livres para escolher aquilo que somos, e, consequentemente, a liberdade moral cede lugar à mera liberdade física.

Outro ponto na filosofia de Hume que permanece conflitante é (III) a afirmação, por um lado, de que há uniformidade na conduta humana, o que nos induz à imutabilidade do caráter; e, por outro lado, a possibilidade do arrependimento, o que poderia nos induzir a conceber a mudança de caráter. Escreve Hume:

O arrependimento purifica todos os crimes, se acompanhado de uma reforma da vida e dos costumes. Como explicar isso? Apenas declarando que as ações tornam alguém criminoso quando elas constituem provas da existência de princípios criminais, em seu espírito; quando, por uma alteração destes princípios, deixam de ser provas concludentes, igualmente deixam de ser criminais ${ }^{54}$.

\subsection{Possíveis soluções que podem ser encontradas a partir da filosofia de Schopenhauer}

\footnotetext{
${ }^{54}$ HUME, D. IEH, Seção 8, segunda parte, p. 103.
} 
Os pontos "I" e "II" podem ser resolvidos pela filosofia de Schopenhauer na medida em que, o idealismo transcendental, absorvido por Schopenhauer a partir de Kant, oferece-nos a vantagem de analisar o problema da liberdade e da necessidade sob uma perspectiva não unidimensional, como Hume o faz, mas bidimensional. Nestes termos, podemos afirmar que o homem é livre sob uma perspectiva, e não o é sob outra, porque cada uma dessas perspectivas não corresponde a uma mesma dimensão, mas para cada perspectiva corresponde uma dimensão igualmente diferente. Assim, afirmar que o homem é livre com referência à sua dimensão inteligível, mas determinado com referência à sua dimensão fenomênica ou empírica, não pode violar o princípio da não-contradição, como Kant muito bem já observara ${ }^{55}$. De fato, na dimensão dos fenômenos ou representação, nada pode ser concebido fora da relação entre fundamento e conseqüência. Aqui, a aplicação do princípio de Wolf, segundo o qual nihil est sine ratio, não oferece exceções. Daquilo que o homem é - isto é, a partir do seu caráter - decorreriam suas motivações e respectivas ações. Mas tal estado das coisas corresponde apenas à dimensão representada, e seu caráter, nestas circunstâncias, é apenas empírico. À parte disto, permanece intacta sua verdadeira essência, que é a sua vontade ou caráter inteligível, os quais não são dados no tempo e no encadeamento causal - isto é, nas formas do fenômeno - mas inteiramente fora do tempo e da lei da causalidade natural. Nesta dimensão do em si, querer e ser se confundem, de forma que aquilo que algo é decorre daquilo se quer ser. O caráter inteligível é o produto de um "ato" inteiramente espontâneo da vontade, o qual, nestes termos, pode apenas ser descrito em termos negativos: um ato não temporal, não espacial, e não subordinado à cadeia causal ${ }^{56}$. Assim, a imputação pode ser justificada, pois apesar da imutabilidade do caráter e da lei da motivação apresentadas na dimensão dos fenômenos, "o resultado é moral, a saber, que naquilo que fazemos, conhecemos aquilo que somos; naquilo que sofremos, conhecemos aquilo que merecemos" (tradução nossa) ${ }^{57}$. Se aquilo que somos decorre daquilo que queremos numa dimensão extratemporal, então obviamente nossas culpas e méritos são de nossa inteira responsabilidade. Em suma, a contradição apontada em "I" é sanada pela adoção de uma dupla dimensão, conforme a proposta do idealismo transcendental; e o problema da imputabilidade suscitado em "II" se resolve na suposição de que todo caráter é obra do

\footnotetext{
${ }^{55}$ KANT, Immanuel. Grundlegung zur Metaphysik der Sitten, p. 94/BA 117.

${ }^{56}$ É claro que semelhante "ato" sequer pode ser considerado um ato. Pensamos que o termo "ato extratemporal da vontade" só pode ser entendido num sentido metafórico, senão alegórico, porque já inserido em um contexto no qual a linguagem, a rigor, não pode penetrar. Portanto, por uma questão de rigor filosófico, semelhante coisa apenas poderia ser descrita utilizando uma linguagem negativa, isto é, não a partir da enumeração de suas propriedades, mas a partir da enumeração das propriedades que não lhe pertencem. Sempre que Schopenhauer ultrapassa o limite da mera linguagem negativa, no ato de descrição da vontade, o resultado só pode ser metafórico ou, conforme dito por Matthias Kossler sobre a questão da vontade como um "estado permanente" - mas que pode ser igualmente dito sobre este "ato extratemporal", embora o próprio Kossler não o tenha percebido - uma mera "comparative form of speech" (cf. KOSSLER, Matthias, Life is but a mirror: on the connection between ethics, metaphysics, and character in Schopenhauer, p. 80).

${ }^{57}$ SCHOPENHAUER, A. P II, §116, p. 247-248.
} 
próprio indivíduo, e que, por essa razão, pode ser compreendido metaforicamente como um "ato extratemporal" de sua vontade, e que tem lugar na dimensão da coisa em si.

O ponto "III", que versa sobre o arrependimento, poderia ser interpretado à luz da doutrina de Schopenhauer referente ao mesmo, para que pudéssemos nos furtar de qualquer contradição. De acordo com Schopenhauer, o arrependimento não indica qualquer transformação do caráter ou vontade do agente, mas meramente o conhecimento de não ter agido de acordo com sua vontade ou caráter ${ }^{58}$. Isso ocorre quando somos conduzidos por motivos e, depois da ação ter sido concretizada, compreendemos que outros motivos, conhecidos apenas posteriormente à ação, eram mais adequados ao nosso caráter; motivos estes que, se conhecidos anteriormente, teriam provocado uma ação oposta ou diversa daquela que de fato se verificou no passado. Mas a apresentação dos motivos é uma função exclusiva do nosso intelecto. A vontade apenas deixa-se conduzir pelo motivo mais forte apresentado pelo intelecto. Portanto, "o arrependimento nunca se origina de a Vontade ter mudado (algo impossível), mas de o conhecimento ter mudado"59. O caráter permanece sempre o mesmo; a única alteração é relativa à compreensão das motivações mais adequadas à essência individual. Consequentemente, agir de forma coerente com nossos verdadeiros propósitos pressupõe amplo conhecimento adquirido ao longo da vida sobre o conjunto de motivos mais adequados à própria vontade. E este é o momento de explorar um outro ponto da filosofia de Schopenhauer, referente ao caráter adquirido. Se, conforme visto, o caráter inteligível é resultado da ação (em sentido metafórico) extratemporal de nossa própria vontade, e o caráter empírico, a manifestação temporal daquele ato, o caráter adquirido, por outro lado, refere-se ao conhecimento que obtemos sobre nós mesmos através de nossa experiência. Portanto, o caráter adquirido seria, de acordo com a bela definição de Schopenhauer, "o conhecimento mais acabado possível da própria individualidade" 60 . Isto é: aquele que adquiriu caráter, é aquele que sabe o que quer, e que age somente de conformidade com o próprio querer. Em suma, é aquele que adquiriu conhecimento dos motivos mais adequados à própria vontade e, assim, sua conduta pode ser imputada ao seu caráter sem qualquer erro. Por essa razão, uma criança jamais pode ser responsabilizada por seus atos tal como um adulto possuidor de longa experiência de vida. A primeira ainda é demasiado carente naquilo que o último já possui suficientemente, que é, a saber, conhecimento abstrato de um amplo conjunto de motivações entre as quais sua vontade elegerá aquela que lhe é mais forte ou adequada. Portanto, percebe-se que neste contexto a imutabilidade do caráter, no âmbito empírico ou fenomênico, não conduz necessariamente à imutabilidade do comportamento, naquele mesmo âmbito. Pois se o comportamento, ou atuação empírica, é fruto da

\footnotetext{
${ }^{58}$ SCHOPENHAUER, A. WWV II, 48, p. 695.

${ }^{59}$ SCHOPENHAUER, A. MVR I, §55, p. 383/I 349.

${ }^{60}$ SCHOPENHAUER, A. MVR I, §55, p. 394/I 359.
} 
ação dos motivos sobre o caráter, e sendo a apresentação de motivos levados à consciência dependente do conhecimento, o qual, por sua vez, é mutável e passível de desenvolvimento ao longo da experiência, então se segue disso que a mudança do conhecimento pode levar a uma mudança do comportamento, ainda que em nada tenha mudado o caráter. Este apenas espera pela apresentação do motivo que lhe é mais adequado. E aqui já podemos desenvolver melhor o problema da imputabilidade na filosofia de Schopenhauer. Pois se culpa e mérito encontram suas raízes no esse, e não no operari, por outro lado é igualmente verdadeiro que o esse apenas pode revelar-se no mundo empírico - e, por conseguinte, julgado com alguma exatidão - quando acompanhado por um conhecimento desenvolvido pela longa experiência, capaz de fornecer à vontade do agente aquele motivo que lhe é mais adequado em cada circunstância. Assim, surpreende-nos quando Schopenhauer diz que o caráter adquirido "é importante não tanto para a ética como para a vida no mundo" ${ }^{61}$. Ao contrário, somos da opinião de que sua teoria do caráter adquirido possui um forte alcance ético, na medida em que nos auxilia a compreender por que razão imputamos moralmente e juridicamente pessoas adultas, possuidoras de longa experiência de vida, mas perdoamos crianças, pessoas de desenvolvimento mental incompleto e até mesmo adultos que, por algum motivo, simplesmente não obtiveram experiência de vida suficiente para ter uma compreensão clara acerca do certo e do errado, do lícito e do ilícito, e, em razão disso, não podem ser suficientemente motivados pela representação de determinadas normas sociais, justamente porque as desconhecem ${ }^{62}$. Em tais casos, o agente ainda está impossibilitado de externar suas reais preferências, ou, dito de outro modo, seu caráter individual. A partir disso é fácil conceber a importância do caráter adquirido para o exercício da liberdade intelectual - melhor explorada por Schopenhauer no pequeno apêndice inserido em seu escrito Über die Freiheit des menschlichen Willens - sem a qual, por sua vez, o indivíduo não pode encontrar os motivos mais adequados ao seu caráter, e, assim, torna-se presa fácil do arrependimento. Certamente, há casos em que a liberdade intelectual pode ser suprimida mesmo quando o caráter já foi adquirido; por exemplo, se pessoas amadurecidas pela experiência sofrem um falseamento duradouro ou momentâneo da compreensão dos motivos devido a doenças ou circunstâncias exteriores, e, consequentemente, não podem externar com exatidão sua própria vontade ${ }^{63}$. Mas isso não anula o fato de que sem o caráter

\footnotetext{
${ }^{61}$ SCHOPENHAUER, A. MVR I, §55, p. 396/I 362.

${ }^{62}$ Podemos imaginar aqui a hipótese de um homem adulto que, embora mentalmente saudável, tivesse sempre vivido em total isolamento em relação aos outros homens, de maneira análoga à experiência que o jovem Kaspar Hauser supostamente vivenciou na Alemanha, no século XIX.

${ }^{63}$ Schopenhauer cita problemas mentais como demência e loucura, e situações como aquelas em que o agente, por causa da escuridão do ambiente, confunde um empregado com um ladrão, e o mata para se defender (cf. SCHOPENHAUER, A. F, p. 140). Poderíamos ainda incluir aqui, a título de curiosidade, uma situação mais anômala, como aquela do "erro de proibição culturalmente condicionado", acolhido pela doutrina jurídica pátria, que consiste na desobediência às leis penais, não porque se desejou desobedecê-las, mas porque era impossível ao agente, naquele momento, compreendê-las e até internalizá-las (cf. ZAFFARONI, E. R. PIERANGELI, J. H. Manual de direito penal brasileiro, v.1, p. 554). Esta impossibilidade de compreensão, por sua vez, deve-se não à falta de longa experiência de vida (portanto, o caráter já foi
} 
adquirido, o exercício pleno daquela liberdade intelectual torna-se simplesmente impossível. De qualquer forma, parece-nos que a prova final pela qual o indivíduo pode com certeza se certificar se a sua conduta correspondeu ou não inteiramente à sua vontade, é o posterior sentimento de arrependimento.

Entendido o arrependimento nestes termos, pode-se aliar a concepção humeana de imutabilidade do caráter com a purificação moral de todos os crimes. Visto que o agente se arrependeu sinceramente de sua conduta passada, isso se deve ao fato de que suas ações pretéritas foram produto não de seu caráter, mas de sua ignorância, a qual é condicionada pela experiência e passível de ser remediada pela mesma.

\section{Conclusão}

Ao longo deste artigo, compreendemos que, na questão da liberdade humana, apesar de Hume e Schopenhauer partirem de premissas muito parecidas, suas conclusões são radicalmente diferentes. Os dois são concordantes, ao menos em linhas mais essenciais, quanto à inflexibilidade com que a lei da causa e efeito direciona o agir dos homens. Pois estes possuem uma natureza geral e um caráter individual fixo, para os quais determinados motivos convergem; do equacionamento entre caráter e motivo, segue-se a ação, como um efeito que deriva de sua respectiva causa. Daí Hume concluir sobre a existência de uma uniformidade do agir humano, pressuposta e comprovada em toda experiência vulgar. No entanto, os problemas na filosofia de Hume surgem quando este procura compatibilizar, na dimensão da própria experiência empírica, a necessidade com a liberdade. Notamos que neste contexto sua definição de liberdade é meramente abstrata, pois se limita à relação entre ação e vontade, sem voltar qualquer atenção - de modo inteiramente injustificado no nosso ponto de vista - aos demais elementos que compõem o fenômeno moral apresentado em sua filosofia, notadamente o da rigidez da natureza específica e individual de todo ser humano. Consequentemente, vimos que a suposição da imutabilidade empírica do caráter também não permite que se justifique, de forma coerente, qualquer imputação ou responsabilidade, e nem mesmo o fenômeno do arrependimento, que posto nos termos do próprio Hume, parece ser contraditório com sua própria filosofia. Por outro lado, pensamos que a

adquirido) mas ao fato de que a experiência de vida de um indivíduo, por pertencer a uma determinada cultura, foi radicalmente diferente da experiência de vida adquirida por indivíduos pertencentes a uma outra cultura. Portanto, é um caso mais próximo do engano momentâneo que o intelecto pode sofrer do que de ausência de aquisição de caráter. Como exemplo desta hipótese, podemos imaginar o caso do silvícola que vai viver em meio à sociedade industrial, e encontra dificuldades de compreender e determinar-se de acordo com certas regras jurídicas e morais vigentes naquela. Certamente, neste caso, não podemos acusar-lhe de ser moralmente mau, mas simplesmente de ser ignorante em relação às nossas regras, e, de fato, no Brasil (só para citar um exemplo), há instrumentos jurídicos que possibilitam até mesmo a isenção de pena em circunstâncias que possibilitam o falseamento dos motivos - como nas "descriminantes putativas" (art. 20, §1 do código penal) e no "erro sobre ilicitude do fato" (art. 21 do código penal). Todas elas figuras legais cuja finalidade é a não atribuição da pena àquele que, afinal, não estava em condições intelectuais favoráveis ao exercício da própria vontade. 
filosofia de Schopenhauer oferece soluções ${ }^{64}$ para estes impasses deixados por Hume, ao supor uma dimensão da coisa em si ao lado da dimensão empírica do homem. Assim, se o caráter é desenvolvido temporalmente e sob a lei da causalidade na dimensão empírica, por outro lado deve-se notar que o tempo e a causalidade são meras condições intelectuais dos fenômenos. Na dimensão do "em si" não vigora nem tempo, e nem causalidade. Consequentemente, a essência de cada indivíduo pode ser entendida como produto de um ato extratemporal de sua própria vontade, a qual, em si, não está submetida a nenhuma forma a priori que vale apenas como condição do mundo como representação. Assim, justifica-se o sentimento de responsabilidade individual e a imputação, porque a liberdade, ao ser deslocada da dimensão empírica para a inteligível, é preservada. Por outro lado, o arrependimento não pode ser entendido como sucedâneo de uma mudança do caráter, mas como simples conseqüência da ignorância sobre os motivos mais coerentes com nosso próprio caráter. Portanto, a compreensão exata do arrependimento na filosofia de Schopenhauer lança novas luzes sobre a questão da imputabilidade, ao fazer a expressão exata do caráter do agente depender, em última instância, do desenvolvimento de seu conhecimento por meio da experiência. Somente dessa forma o intelecto é apto a conceder um amplo conjunto de motivações entre as quais a vontade pode escolher aquela que lhe é mais adequada em cada circunstância. A falta de conhecimento acerca do motivo mais adequado à própria vontade conduz a uma ação incoerente com o próprio caráter - incoerência esta que se comprova mais tarde, mediante o sincero sentimento de arrependimento que acomete o agente.

\section{Referências}

BRASIL. Decreto-lei n. 2.848, de 7 de dezembro de 1940. Código Penal. Vade Mecum universitário RT. 3. ed. São Paulo: Editora Revista dos Tribunais, 2011.

COSTA, Claudio. Como ser um bom compatibilista. Princípios, v. 7, n. 8. Natal, 2000.

HUME, David. Investigação acerca do entendimento humano. Tradução de Anoar Aiex. São Paulo: Nova Cultural, 2004.

\footnotetext{
${ }^{64}$ Não queremos com isso ressaltar qualquer aproximação histórica entre Schopenhauer e Hume, no sentido de pretender evidenciar, através deste trabalho, que o indivíduo Schopenhauer teria pretendido formular sua teoria da liberdade da vontade humana motivado pelo objetivo de apresentar, especificamente, soluções à filosofia de Hume - embora, inegavelmente, Schopenhauer conhecesse a filosofia humeana. O que queremos dizer é que a filosofia de Schopenhauer pode ser conceitualmente associada à filosofia de Hume, e, feita essa associação no âmbito estritamente conceitual - sem nos ater a investigações de caráter histórico -, ressaltando os pontos nos quais os dois filósofos inegavelmente coincidem, podemos, então, utilizar as ideias de um como soluções para as ideias do outro, naqueles pontos nos quais as coincidências desaparecem, e as diferenças e dificuldades surgem.
} 
Revista Voluntas: Estudos sobre Schopenhauer - Vol. 3, Números 1 e 2 - $1^{\circ}$ e $2^{\circ}$ semestres de 2012 - ISSN: 2179-3786 - pp. $265-290$.

. Tratado da natureza humana. Tradução de Déborah Danowski. 2. ed. revista e ampliada. São Paulo: UNESP, 2009.

JACQUETTE, Dave. The philosophy of Schopenhauer. Chesham: Acumen, 2005.

JANAWAY, Christopher. Schopenhauer's philosophy of value. In: Better consciousness: Schopenhauer's philosophy of value. Edited by Alex Neill and Christopher Janaway. Oxford: Wiley-Blackwell, 2009.

KANT, Immanuel. Grundlegung zur Metaphysik der Sitten. Werke in sechs Bänden. Band IV. Ed. de Wilhelm Weischedel. Wiesbaden: Insel, 1956.

. Crítica da razão pura. Tradução de Valerio Rohden e Udo Baldur Moosburger. São Paulo: Nova Cultural, 1999.

KOSSLER, Matthias. Life is but a mirror: on the connection between ethics, metaphysics and character in Schopenhauer. In: Better consciousness: Schopenhauer's philosophy of value. Edited by Alex Neill and Christopher Janaway. Oxford: Wiley-Blackwell, 2009.

MAGEE, Brian. The philosophy of Schopenhauer. Revised and enlarged edition. New York: Oxford University Press, 2009.

PAVÃO, Aguinaldo. O mal moral em Kant. Curitiba: CRV, 2011.

SCHOPENHAUER, Arthur. Die Welt Als Wille und Vorstellung, II. Ed. de Arthur Hübscher. Zürich: Diogenes, 1977.

. O mundo como vontade e como representação. Tradução, apresentação, notas e índices de Jair Barboza. São Paulo: Editora UNESP, 2005.

. Parerga und Paralipomena. Zweiter Band. Ed. de Arthur Hübscher. Zürich: Diogenes, 1977.

. Sobre o fundamento da moral. Tradução de Maria Lúcia Mello Oliveira Cacciola. 2. ed. São Paulo: Martins Fontes, 2001.

1977.

. Über die Freiheit des menschlichen Willens. Ed. de Arthur Hübscher. Zurique: Diogenes,

. Über die vierfache Wurzel des Satzes von zureichenden Grund. Ed. de Arthur Hübscher. Zürich: Diogenes, 1977.

ZAFFARONI, Eugenio Raul. PIERANGELI, José Hnrique. Manual de direito penal brasileiro, v.1, parte geral. 7. ed. revisada e atualizada. São Paulo: Editora Revista dos Tribunais, 2007. 
ROGÉRIO MOREIRA ORRUTEA FILHO

Aprovado: 25/11/12

Approved: 11/25/12 